\title{
Dave Raffaelli \\ Interactions between macro-algal mats and invertebrates in the Ythan estuary, Aberdeenshire, Scotland
}

Received: 14 December 1998 / Received in revised form: 26 May 1999 / Accepted: 28 May 1999

\begin{abstract}
Blooms of opportunistic green macro-algae are a common feature of coastal areas and their effects on mudflat invertebrates can be dramatic. On the Ythan estuary, Aberdeenshire, Scotland, we have carried out a number of manipulative field experiments designed to evaluate the effects on invertebrates of different species of macro-algae with contrasting ecologies, and the effects of invertebrates on the development of the blooms. Macro-algal mats were found to have dramatic negative effects on the density of the amphipod Corophium volutator, with higher algal biomasses having greater impact. The mechanism for this interaction seems to be interference by the algal filaments with the feeding behaviour of the amphipod. In contrast, the polychaete $\mathrm{Ca}$ pitella spp. increases in abundance under macro-algal mats due to enrichment of the sediment with organic material. These two interactions are seen at all scales, in areas of less than $1 \mathrm{~m}^{2}$ to the scale of the entire estuary, irrespective of the species composition of the macroalgal mats. Bioturbation by Corophium and grazing by the snail Hydrobia ulvae had little effect on macro-algal biomass, but there were less algae when the polychaete Nereis diversicolor was present. The most significant interaction in this system is the pronounced negative impact of algal mats on the abundance of Corophium, probably the most important invertebrate species in the diets of the estuary's shorebirds, fish and epibenthic crustaceans.
\end{abstract}

Key words Corophium - Enteromorpha - Eutrophication . Ythan estuary $\cdot$ Macro-algae

Communicated by H. Asmus and R. Asmus

D. Raffaelli (

Culterty Field Station, Department of Zoology,

University of Aberdeen, Newburgh, Ellon, AB41 6AA, Scotland

e-mail: d.raffaelli@abdn.ac.uk

\section{Introduction}

Large-scale blooms of opportunistic macro-algae have been reported from many coastal shallow-water areas world-wide (Fletcher 1996), including the Wadden Sea (Reise and Siebert 1994). These mats can impact significantly on invertebrate assemblages, causing declines in some species and increases in others (Raffaelli et al. 1998). Nowhere is this seen more clearly than in the Ythan estuary, $20 \mathrm{~km}$ north of the city of Aberdeen on the east coast of Scotland. The estuary is only $8 \mathrm{~km}$ in length and only a few hundred metres (max) in width. The river Ythan drains about $650 \mathrm{~km}^{2}$ of land, almost all of which is under intense arable agriculture. In line with much of the rest of Europe, the amount of nitrogenous fertiliser applied to crops in the catchment has increased substantially and there has been a shift towards cereals and oil-seed rape (Raffaelli 1998, 1999). Not surprisingly, the levels of dissolved oxidised nitrogen in the river have increased over the past 30 years and these levels are reflected in the receiving estuary (Balls et al. 1995; Raffaelli 1999). Analysis of aerial photographs taken in mid-summer at low tide show that in 1954 and 1969, green macro-algal mats (only biomasses $>1 \mathrm{~kg} \mathrm{~m}^{-2}$ wet weight show up on the photographs) were then much less widespread than in the 1980s and 1990s (Fig. 1), and there have been concomitant changes in the Ythan's invertebrates and shorebirds (Raffaelli et al. 1999). Whilst most of the interactions described to date concern the negative impacts of macro-algal blooms on invertebrates (Raffaelli et al. 1998), invertebrates may also have impacts on macro-algae, especially at low algal biomasses. In this paper, I discuss these interactions for the Ythan estuary, with particular emphasis on the amphipod Corophium volutator. This species seems particularly sensitive to macro-algal mats and is a major food item for most of the Ythan's shorebirds, fish and epibenthic crustaceans (Hall and Raffaelli 1991). 
Fig. 1 Temporal changes in the area of macro-algal mats in different sections of the Ythan estuary, Aberdeenshire. Data from aerial photographs, on which biomasses $>1 \mathrm{~kg} \mathrm{~m}^{-2}$ (wet weight) are apparent (modified from Raffaelli et al. 1999)

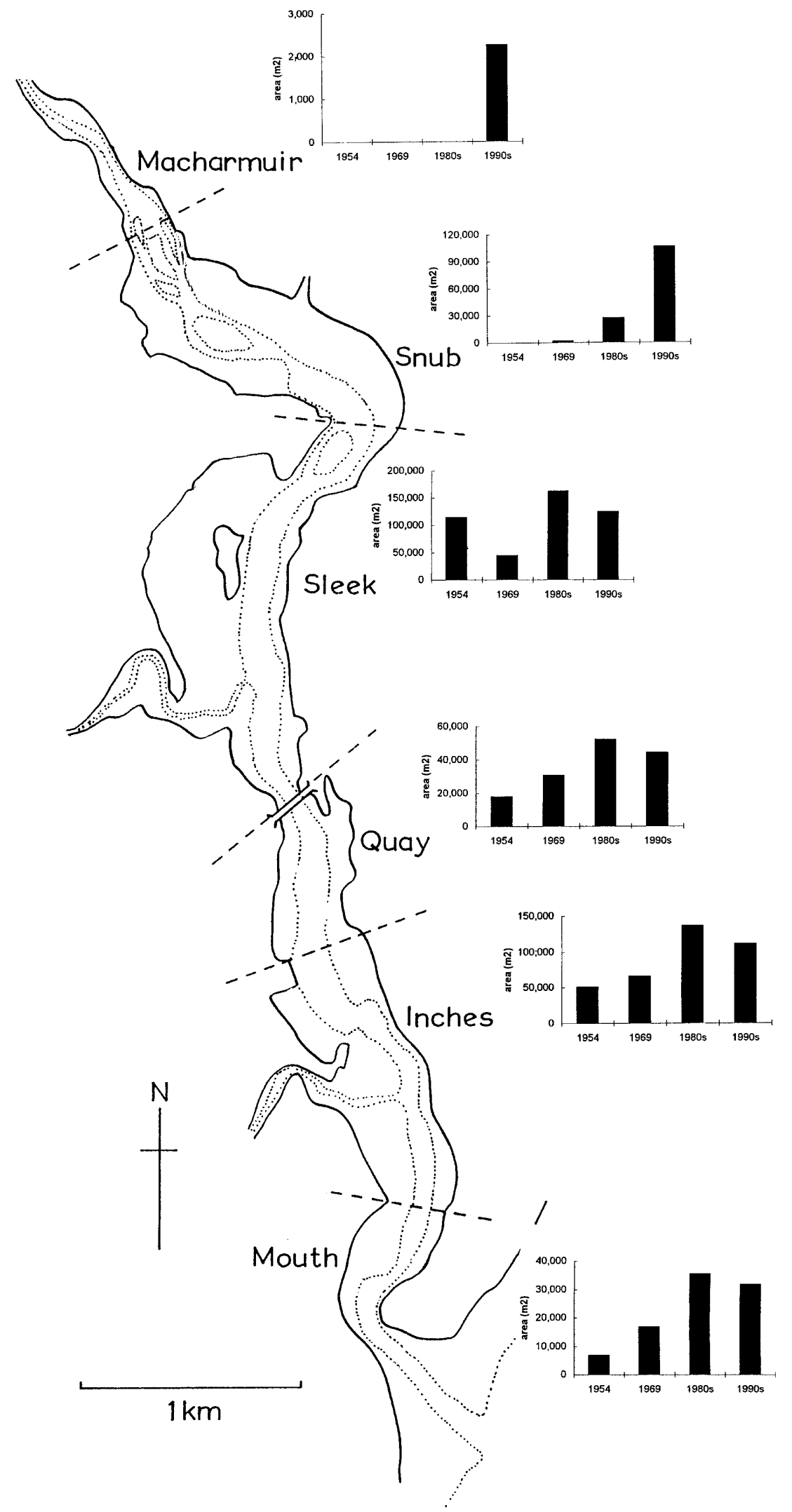




\section{Effects of mats on invertebrates}

Evidence for negative impacts of macro-algal mats on invertebrates comes from four kinds of investigation carried out over a range of spatial and temporal scales.

\section{Small-scale studies}

The spatial distribution of algal mats is heterogeneous over a range of scales. At the estuary scale, mats are confined to certain sections (see below) and within mataffected areas, there are often mat-free patches, several square metres in extent. Small-scale comparisons of patches $\left(<1 \mathrm{~m}^{2}\right)$ of mudflat with and without a covering of macro-algal mats have consistently revealed few Corophium volutator (sometimes none) and many Capitella spp. under mats, whilst the converse is true for matfree patches (Fig. 2). These small-scale effects have been reproduced on many occasions in numerous undergraduate and postgraduate projects carried out at the University of Aberdeen, and the effects are consistent and predictable, at least for these two taxa.
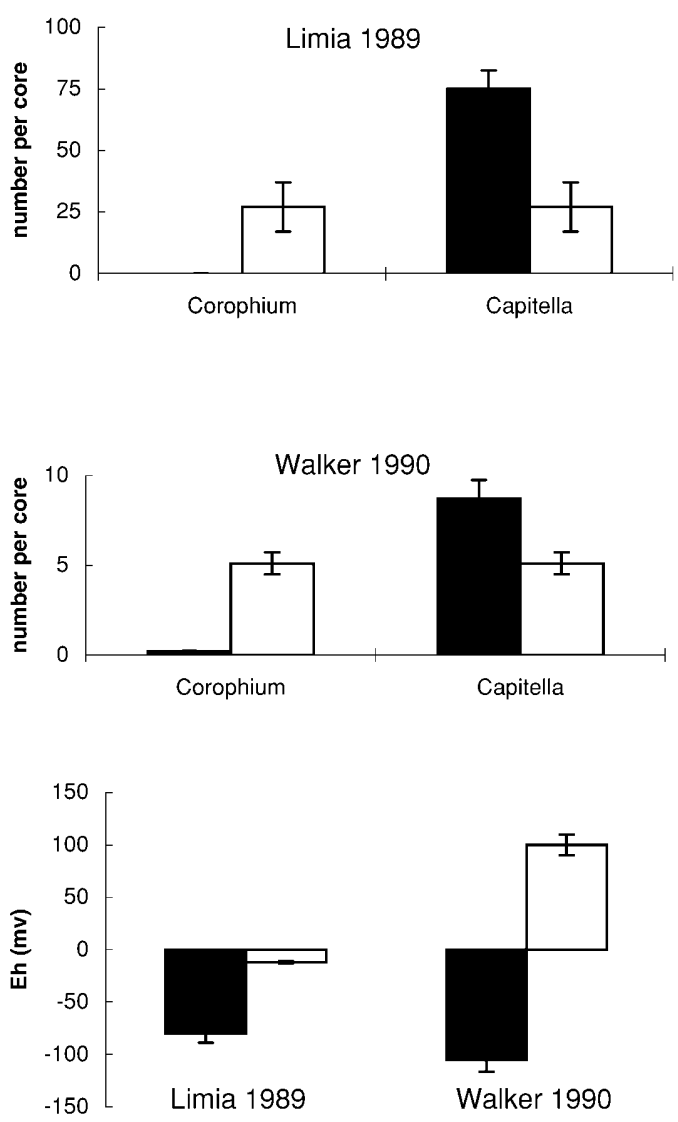

Fig. 2 Mean abundance $(7.5 \mathrm{~cm}$ diameter corer) of Corophium volutator and Capitella spp., and redox potential at $4 \mathrm{~cm}$ depth, in small-scale patches of sediment covered by macro-algal mats (solid bars; $n=5$ cores) and in algal-free areas (open bars; $n=5$ cores), Newburgh Quay, autumn 1987 (Limia 1989) and summer 1990 (Walker 1990)
A similar pattern of abundance is seen when macroalgae are cleared from large $(4 \mathrm{~m} \times 4 \mathrm{~m})$ areas from within extensive contiguous mats of Enteromorpha. Corophium is able to recolonise algal-free areas (Fig. 3), but within a few weeks these individuals are excluded as the mats re-develop (Okora 1989). Corophium juveniles can probably disperse widely in the Ythan (Lawrie and Raffaelli 1998) but, if the mats are sufficiently dense (>2-3 $\mathrm{kg} \mathrm{m}^{-2}$ wet weight) so that they generate a hostile sediment environment, or so extensive that recruits have to travel large distances from an unaffected area, then algal-free patches within mats are only slowly recolonised, if at all. This is clearly seen in Fig. 3, where the amount of recolonisation declines with increasing distance of the cleared plot from the nearest source of Corophium, an unaffected area of mudflat.

Similarly, if Chaetomorpha is experimentally removed during the summer by clipping $0.25 \mathrm{~m}^{2}$ plots to prevent mat development, then these algae-free areas have higher Corophium densities than in sediments underlying Chaetomorpha mats (Fig. 4; Cha, in preparation).

Intensive study at a single site over a long time

Larger-scale evidence of interactions between algal mats and invertebrates comes from one particularly welldocumented area of the Ythan (Newburgh Quay), where estimates of Corophium have been made over many years in relation to the feeding ecology of shorebirds (Raffaelli et al. 1991). Here, there have been changes in the local population of Corophium over time, concomi-

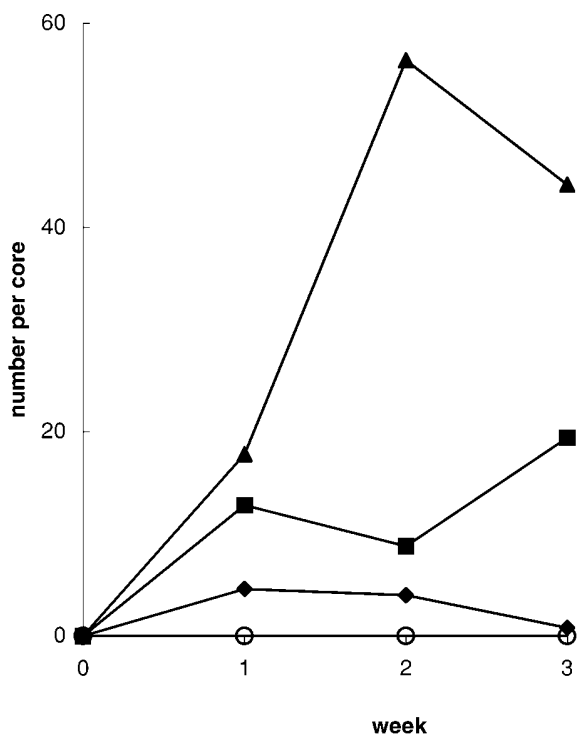

Fig. 3 Recolonisation of Corophium volutator in three $16 \mathrm{~m}^{2}$ areas cleared within dense extensive algal mats, summer 1989. Solid triangles are nearest to unaffected areas of mudflats (source of Corophium recruits) and solid diamonds are furthest away (see text). Open circles are data from an adjacent macro-algal mat ( $2 \mathrm{~kg} \mathrm{~m}^{-2}$ wet weight). Week 0 is 1 June. Data from Okora (1989) 


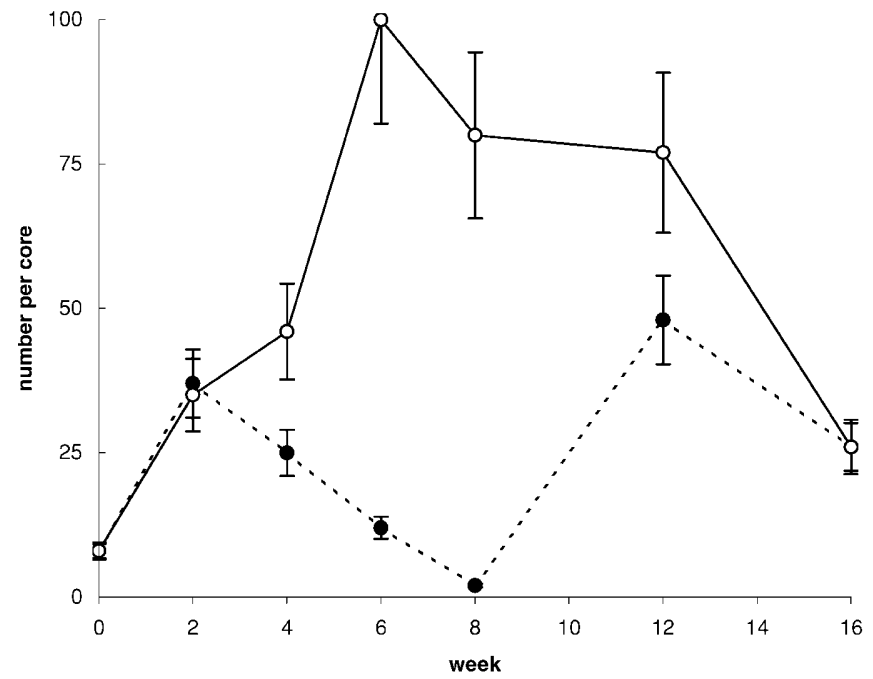

Fig. 4 Mean abundance $(7.5 \mathrm{~cm}$ diameter corer) of Corophium volutator in replicate $(n=6) 0.25 \mathrm{~m}^{2}$ areas on the Sleek of Tarty, Ythan estuary, from which Chaetomorpha was regularly clipped at the sediment surface (open circles) and under developing mats of Chaetomorpha (solid circles). Week $0=1$ May 1994. Data from Cha, in preparation

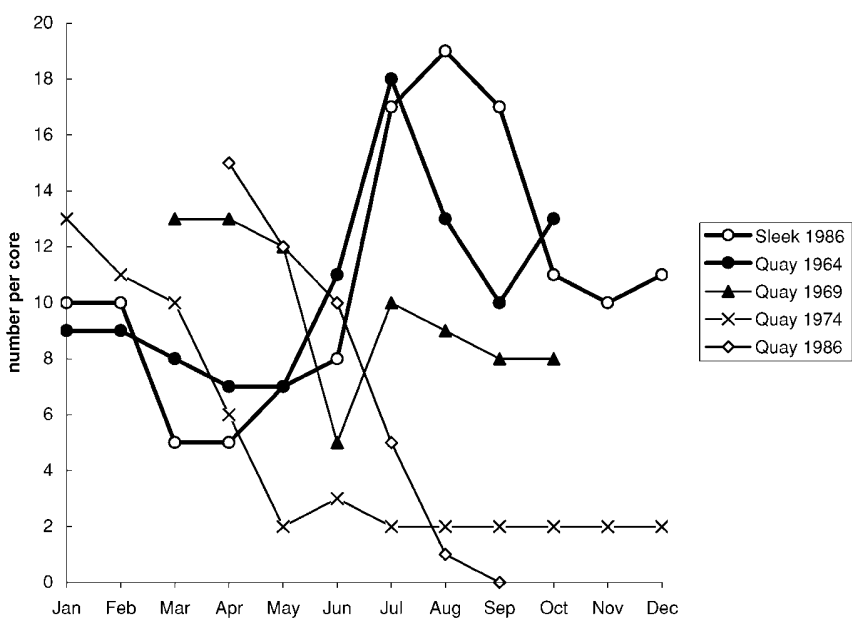

Fig. 5 Seasonal cycle of abundance of Corophium volutator at South Quay between 1964 and 1986, when macro-algal biomass was increasing from a few hundred $\mathrm{g} \mathrm{m}^{-2}$ to several $\mathrm{kg} \mathrm{m}^{-2}$, and at the Sleek of Tarty in 1986, at that time relatively unaffected by macro-algae. Data from Raffaelli et al. (1991). Densities scaled to a standard corer size of $7.5 \mathrm{~cm}$ diameter

tant with an increase in the biomass of opportunistic green macro-algae at that site (Raffaelli et al. 1989). In the 1960s, when macro-algal biomass was typically a few hundred $\mathrm{g} \mathrm{m}^{-2}$ (dry weight) at this site, the seasonal cycle of abundance of Corophium was similar to that observed in areas unaffected by macro-algae, such as the Sleek of Tarty area of the Ythan (Fig. 5). It seems that the normal increase in Corophium in the spring has been progressively impacted by the macro-algal bloom which develops at the same time. At low algal biomasses in the 1960s this had little effect on Corophium, but at the high biomasses recorded in the 1980s, Corophium is effectively excluded from this site.

Unfortunately, there are few data available for other invertebrate taxa at this location, except for Hydrobia ulvae, but these data are difficult to interpret (Shearer 1997). Densities of Hydrobia increased dramatically at this site up to the mid-1970s, with a subsequent decline through the 1980s and 1990s. However, the Hydrobia data from the 1970s are from studies (Buxton 1975; Green 1977; Joffe 1978) which employed a smaller mesh size $(0.5$ or $0.25 \mathrm{~mm})$ than those in the $1960 \mathrm{~s}$ and $1990 \mathrm{~s}$, so that these trends may be more apparent than real. Also, Armonies and Hartke (1995) have shown that in the Wadden Sea, hydrographic factors may drive distribution patterns in this species because of its floating habit, so that it may reflect local environmental conditions less well.

\section{Long-term, estuary-scale changes}

Estuary-scale invertebrate data are available for the late winter-early spring period of 1964, 1990 and 1997 (Raffaelli et al. 1999) for Corophium volutator, H. ulvae, Macoma balthica and Nereis diversicolor. The 1964 survey was undertaken by Goss-Custard (1966) to provide information on the densities of invertebrates important in the diet of wading shorebirds. At this time macro-algal blooms were not a prominent feature of the estuary (Raffaelli et al. 1999). The 1990 survey represents a period when macro-algal mats $\left(>1 \mathrm{~kg} \mathrm{~m}^{-2}\right.$ wet weight) were widespread, covering about $40 \%$ of the intertidal area (Fig. 1). It should be noted that the algal biomasses shown in Fig. 1 at upstream locations in the 1990s were not present when the 1990 survey was carried out and, in any case, represent only small biomasses (note scale on $y$-axis). The 1997 survey was carried out in response to an unusually low macro-algal biomass recorded the previous (1996) summer, probably a result of a major flood event during the 1995-1996 winter (Raffaelli et al. 1999).

Analysis of these three surveys (Fig. 6) reveals: (1) a decline in Corophium between 1964 and 1990 in areas of the estuary then affected by macro-algal mats, (2) an increase in Corophium between 1964 and 1990 in areas of the estuary (mostly upstream) then not affected by mats, and (3) a recovery in Corophium between 1990 and 1997 in those areas (mostly downstream) from which mats had disappeared the previous summer (Fig. 6). Macoma and Nereis (but not Hydrobia) also increased in upstream (unaffected) locations between 1964 and 1990, probably due to an overall increase in the Ythan's productivity (Raffaelli et al. 1999).

The decline of Corophium between 1964 and 1990 in areas affected by algal mats is consistent with the results of the small-scale surveys and the long-term trends seen at Newburgh Quay (see above). The low macro-algal biomass in the summer of 1996 was accompanied by an increase in Corophium densities the following winter and 
Fig. 6 Abundance of Corophium volutator in different sections of the Ythan estuary in 1964, 1990 and 1997. Abundances are in classes in order to conform to the initial survey carried out by Goss-Custard (1966), as follows: $l=<14$, $2=15-29,3=30-44,4=45-59$, $5=60-120,6=>120$, individuals per $100 \mathrm{~m}^{2}$. Data from Raffaelli et al. (1999).

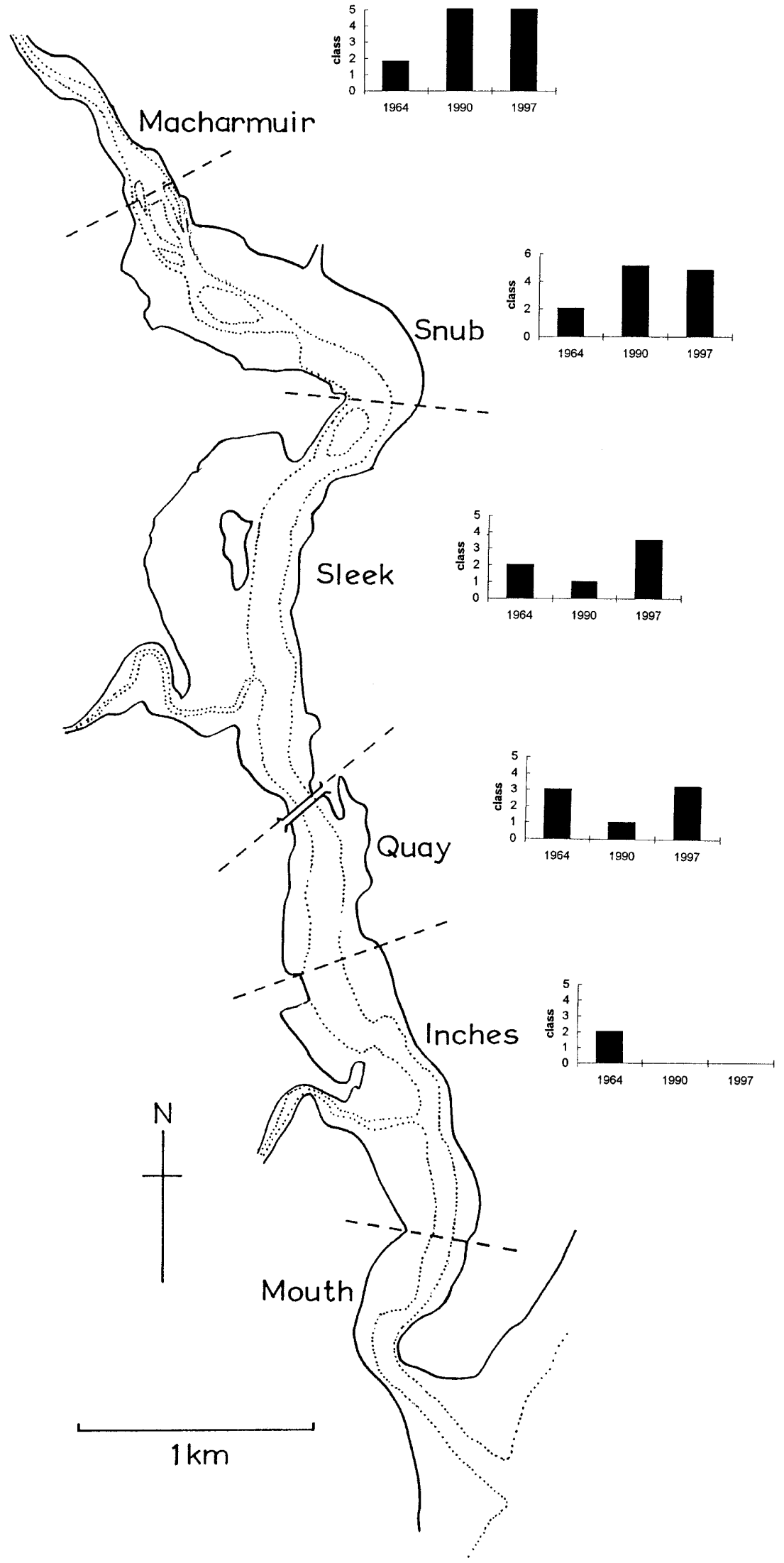


Expt 1, week 10
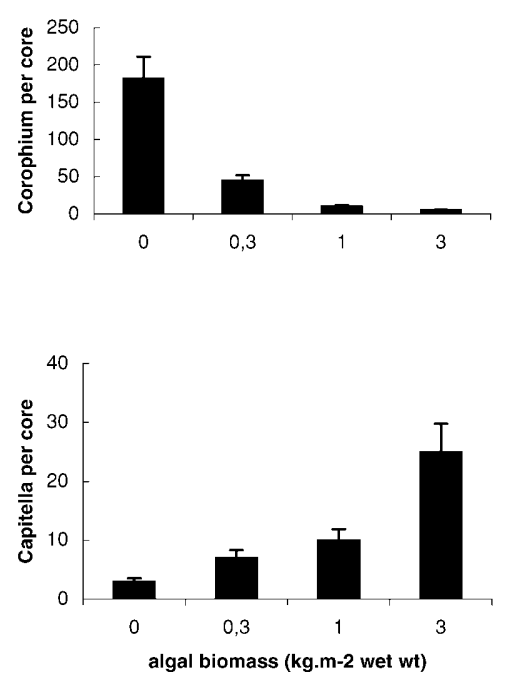

Expt 1, week 22
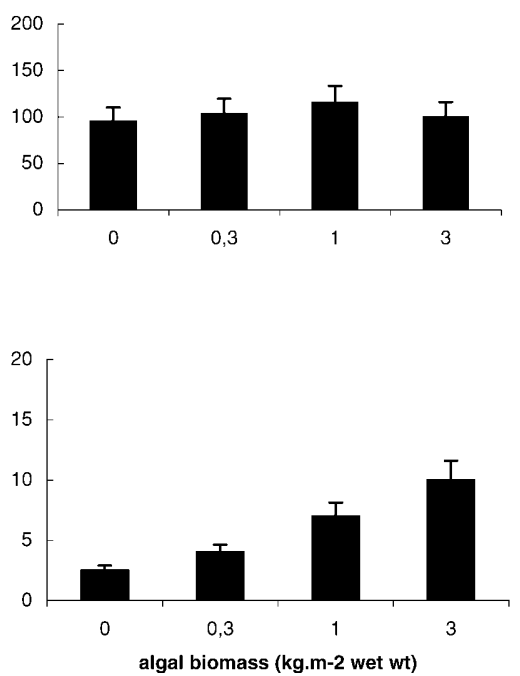

Expt 2
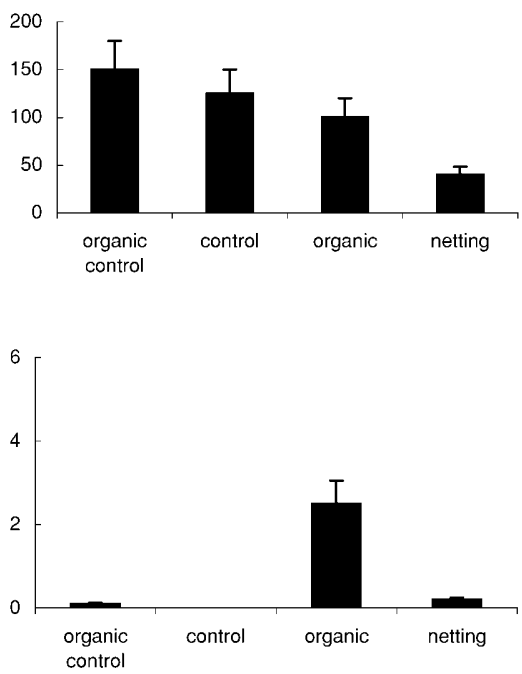

Fig. 7 Abundance of Corophium volutator and Capitella spp. in two field experiments, Sleek of Tarty, Ythan estuary. In the first experiment, macro-algal biomasses were applied to replicate areas of previously unaffected mudflat and sampled at weeks 10 (left) and 22 (centre). In the second experiment, replicate areas of sediment were treated with organic material $(O)$, fine nylon netting $(N)$, with appropriate controls of undisturbed sediment $(C)$ and sediment treated in the same way as in the organic enrichment treatment $(O C)$. Data from Raffaelli et al. (1998). Corer size was $7.5 \mathrm{~cm}$ diameter in both experiments

can be viewed as a natural large-scale experimental test of the hypothesised negative impact of macro-algal mats on this species.

\section{Field experiments}

Controlled manipulative experiments at the estuary-scale are not feasible, but such experiments have been performed at an appropriate small-scale by Hull $(1987,1988)$ and Laurent and Raffaelli (in preparation). In Hull's first experiment (Hull 1987), replicate $5 \mathrm{~m}^{2}$ areas of previously unaffected mudflat were dosed with zero, $300 \mathrm{~g}, 1 \mathrm{~kg}$ or 3 $\mathrm{kg}$ (wet weight) $\mathrm{m}^{-2}$ of green macro-algae (mostly Enteromorpha spp.) and sampled after 10 and 22 weeks. After 10 weeks, numbers of Corophium had declined and numbers of Capitella had increased with increasing macro-algal biomass (Fig. 7). By week 22, the macro-algae had been removed from the experimental plots by attrition, wave action and burial and Corophium recovered, whilst densities of Capitella remained high in the high biomass plots (Fig. 7). On the basis of these results, Hull (1987) suggested that the effect of macro-algal mats on Corophium is mostly physical, the algal filaments interfering with the normal deposit-feeding behaviour of Corophium at the sediment-water interface. In contrast, the effects on Capitella are probably due to an enrichment of the sediment, which persisted even when the surface macro-algal material was removed.
To test these propositions, Hull carried out a second experiment where the physical and enrichment effects were separated by applying inert nylon filaments to the sediment surface or adding finely-ground dried Enteromorpha (Hull 1988; Raffaelli et al. 1991). As predicted, Corophium abundance was significantly affected by the nylon filaments but not by enrichment, whilst Capitella increased only in the enrichment treatment (Fig. 7). The responses of other species in these experiments were inconsistent, but have been discussed elsewhere (Raffaelli et al. 1998).

In summary, small-scale studies, long-term intensive and extensive surveys and controlled manipulative experiments all provide compelling evidence that macroalgal mats have pronounced negative effects on Corophium volutator. This species occurs in the diets of many shorebirds, fish and epibenthic crustacean predators on the Ythan (Hall and Raffaelli 1991) and its decline over large areas (40\%) of the intertidal flats is of concern. Restoring Corophium populations in the Ythan will require measures targeted at macro-algal mats. These mats comprise at least three genera Enteromorpha, Ulva and Chaetomorpha and probably many species. The estuaryscale data on long-term trends in macro-algal mats (Fig. 1) probably confounds all three genera, since these cannot be distinguished on the aerial photographs and they were unlikely to be separated in the biomass estimates made at Newburgh Quay between the 1960s and 1980s. It is also likely that the mats used in the field experiments described above were a mixture of different species.

Ulva, Enteromorpha and Chaetomorpha might be expected to have different impacts on invertebrate assemblages because of the gross differences in their growth form and ecology. On the Ythan, Ulva is only loosely associated with the sediment surface, sometimes simply lifting off the surface with the tide. Ulva tends to be more abundant in the upper reaches of the estuary, reaching peak abundance in late summer-early autumn 
Fig. 8 Seasonal changes in the mean ( $n=5$ quadrats) biomass (dry weight per $0.25 \mathrm{~m}^{2}$ ) of main green macro-algal genera at different sites on the Ythan estuary $(2=$ downstream,

$7=$ upstream), over the summer of 1998
Ulva
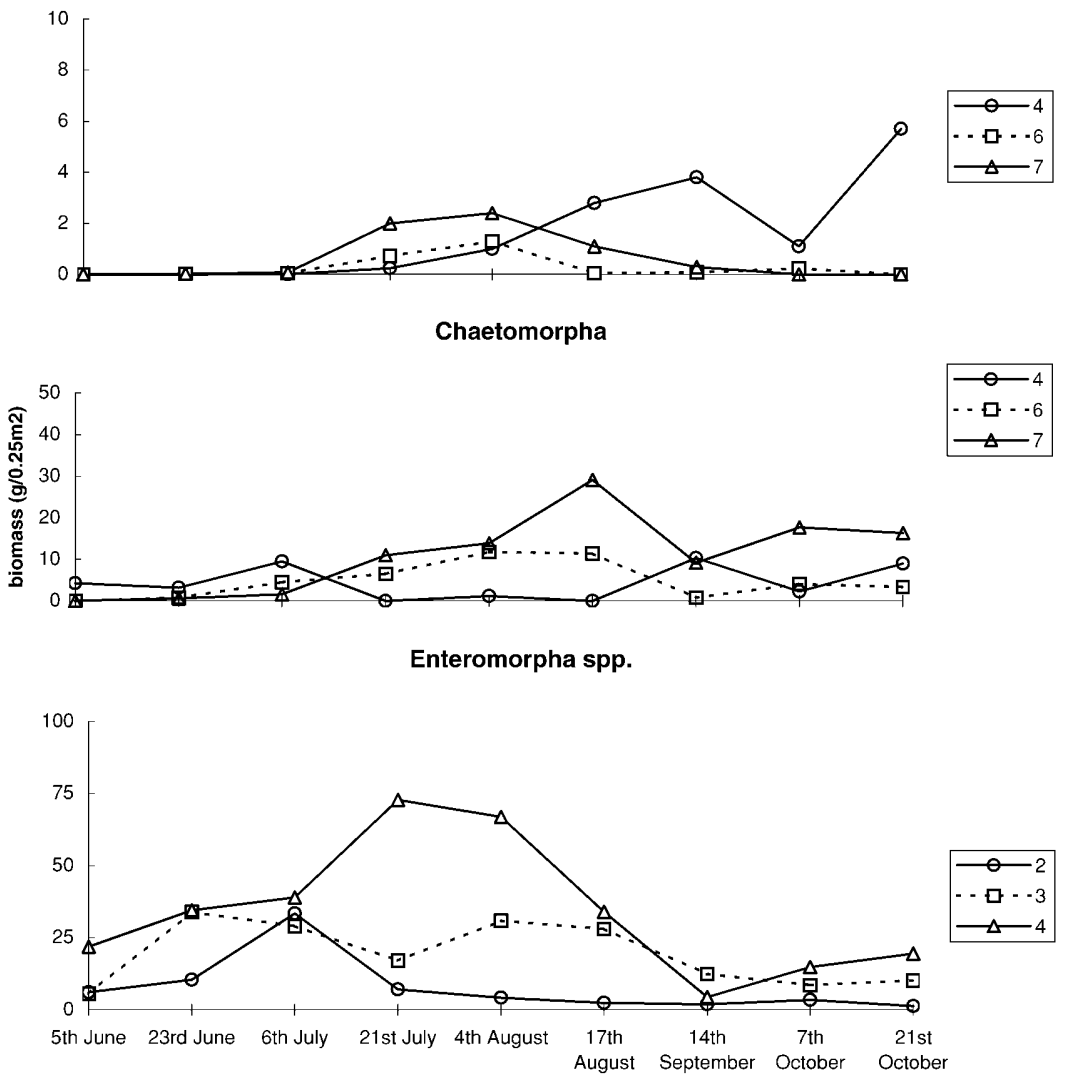

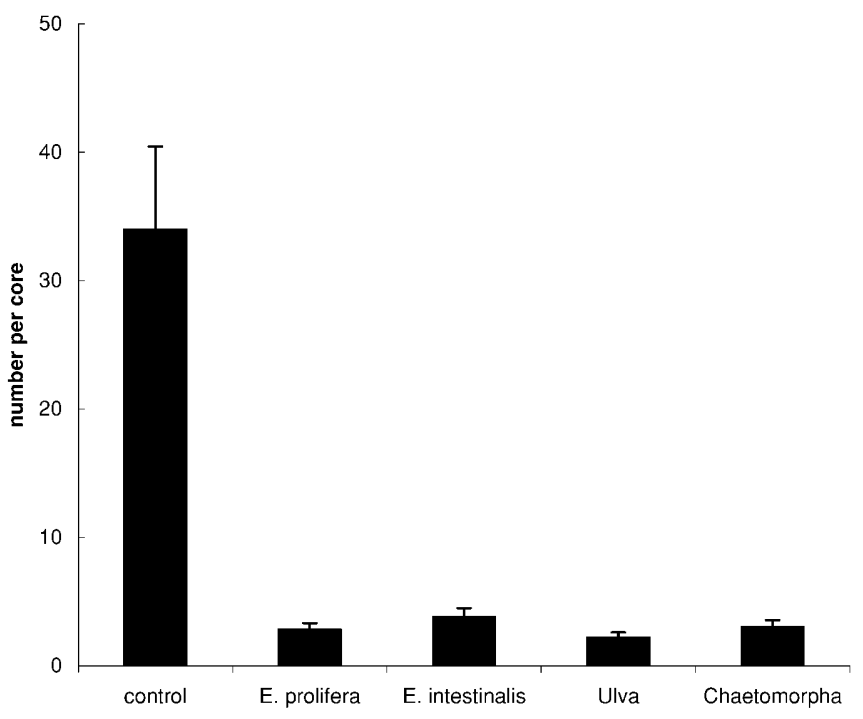

Fig. 9 Abundance of Corophium volutator after 6 weeks under equivalent biomasses $\left(1 \mathrm{~kg} \mathrm{~m}^{-2}\right.$ wet weight $)$ of different algal taxa, and in algal-free controls, autumn 1997, Tarty Burn, Ythan estuary. Data from Laurent and Raffaelli, in preparation

(Fig. 8). In contrast, Chaetomorpha is intimately associated with the sediment, often creating a dense matrix of filaments extending several $\mathrm{cm}$ beneath the surface. Chaetomorpha is characteristic of the middle and upper reaches of the estuary and blooms somewhat earlier than
Ulva, in mid-summer (Fig. 8). Enteromorpha is widespread in the lower and middle reaches of the Ythan and is often anchored in the mud so that it also forms a dense filamentous matrix. There are probably several (undetermined) species of Enteromorpha on the Ythan (Rebecca Taylor, personal communication), which reach peak biomass at different times of the year (Fig. 8).

Given their different ecologies, it is possible that these three macro-algal genera will have different effects on invertebrate populations. Laurent and Raffaelli (in preparation) tested this hypothesis in a manipulative field experiment whereby mats of biomass $1 \mathrm{~kg} \mathrm{~m}^{-2}$ (wet weight) of Ulva, Chaetomorpha and two "species" of Enteromorpha were applied to replicate areas of mudflat. The effects on Corophium were similar for all three algal taxa - a dramatic decline in abundance (Fig. 9). The effects on other species will be discussed elsewhere (Laurent and Raffaelli, in preparation).

\section{Effects of invertebrates on macro-algae}

All three genera of green macro-algae on the Ythan have a range of invertebrate consumers (Hall and Raffaelli 1991), and Green (1977) estimated that H. ulvae alone consumed 5-10\% of the standing crop of Enteromorpha. Field experiments set up in early summer comprising replicate cages containing either 500 Hydrobia $100 \mathrm{~cm}^{-2}$ or no Hydrobia, found no effect on Enteromorpha bio- 


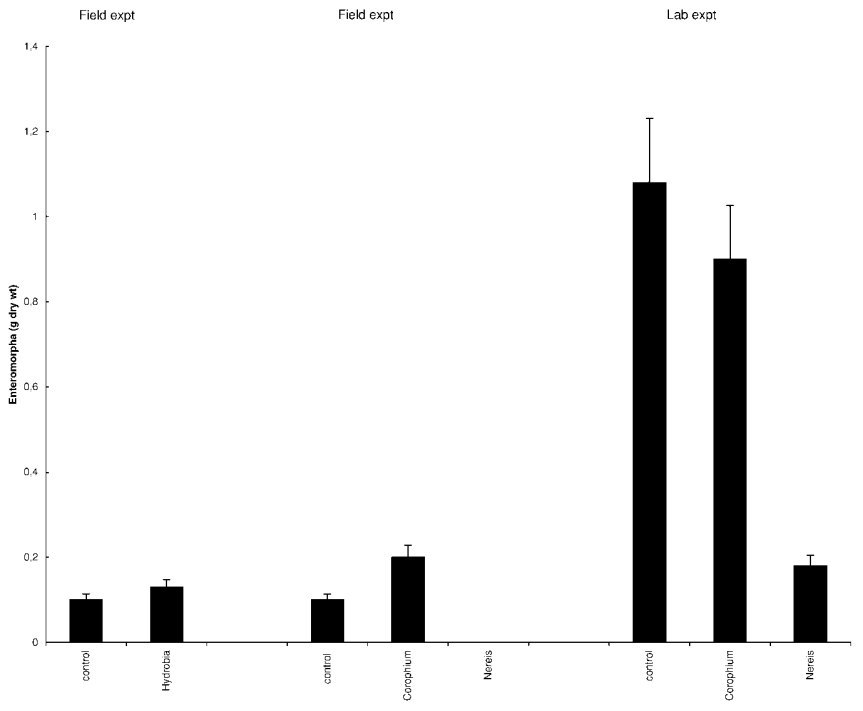

Fig. 10 Effects of Hydrobia ulvae, Corophium volutator and Nereis diversicolor on Enteromorpha biomass from field and laboratory experiments. In the field experiments, invertebrates were maintained in replicate $(n=5) 10 \mathrm{~cm}$ diameter corers sunk to $10 \mathrm{~cm}$ depth and roofed with a $500 \mu \mathrm{m}$ mesh. The laboratory experiments were carried out using replicate $(n=4)$ jars $(8 \mathrm{~cm}$ diameter, $7 \mathrm{~cm}$ deep) for each treatment, half-filled with natural azoic sediment and topped with estuary water which was aerated. The field experiments ran for 5 weeks and the laboratory experiment for 16 days. Data from Shearer (1997) and Ventura (1997)
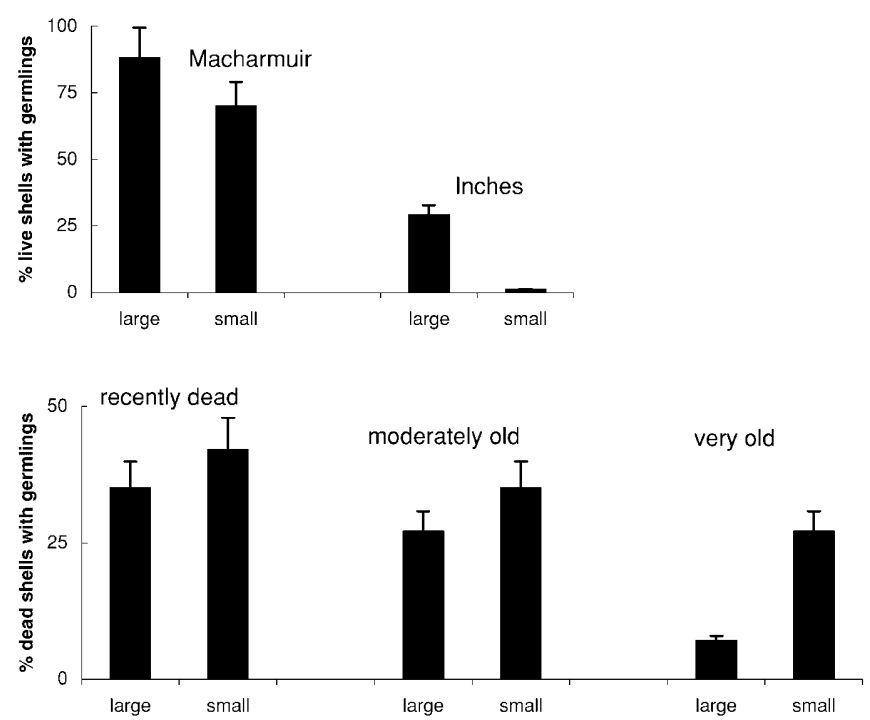

Fig. 11 Incidence of germlings of Enteromorpha on live ( $n=50$, each site) and dead ( $n=50$, each site) shells of Hydrobia ulvae. Large snails are $>4 \mathrm{~mm}$ in shell height and small shells $<4 \mathrm{~mm}$. Macharmuir supports little macro-algae, whilst Inches regularly experiences algal blooms (see Fig. 1). Dead shells were aged according to their physical appearance. Data from Shearer (1977)

mass after 5 weeks (Fig. 10). Wilhelmsen and Reise (1994) similarly concluded that grazing by Littorina littorea is unlikely to control the development of macroalgal mats in the Wadden Sea. A similar experiment to assess the impact of Corophium (250 per $\left.100 \mathrm{~cm}^{2}\right)$ and
Nereis (10 per $100 \mathrm{~cm}^{2}$ ) on the development of an Enteromorpha bloom in early summer (Ventura 1997) showed an effect of Nereis but not of Corophium (Fig. 10). These interactions were confirmed in laboratory experiments where Enteromorpha filaments were added to containers with either Nereis or Corophium (densities as above) or neither (Fig. 10). Here again, Nereis had a significant effect on above-ground algal biomass.

In the Wadden Sea, Hydrobia may play a positive role in the development of macro-algal mats by providing a suitable substrate for settlement and germination (Schories and Reise 1993). Live Hydrobia were collected from two areas on the Ythan during the summer from two sites: one with a long history of macro-algal blooms (Inches) and a second site (Macharmuir) where macroalgae are rare or absent (Shearer 1997). These data showed that large (>4 $\mathrm{mm}$ height) shells have a higher incidence of germling Enteromorpha than smaller shells, but the site which regularly experiences algal blooms had a lower incidence of fouling (Fig. 11), contrary to expectations.

Dead Hydrobia shells accumulate in large drifts in the middle section of the estuary (Sleek of Tarty), probably due to local circulation effects (Armonies and Hartke 1995). Examination of these shells also showed a significant number with germlings (Fig. 11), with proportionately more on recently dead shells (cf. Schories and Reise 1993). Most fouled shells only had one germling, with a maximum of six on some dead shells (Shearer 1997).

Reise (1983) argued that burrowing polychaetes might have a positive effect on the development of algal mats in the Wadden Sea, by anchoring filaments in the burrows. In the laboratory experiments described above, algal filaments were found attached up to $3.5 \mathrm{~cm}$ deep in the sediment in the Nereis treatment, the deeper filaments intertwined and glued together with mucus (Ventura 1997). There was no anchorage of filaments in the Corophium treatment.

\section{Conclusions}

Interactions between macro-algal mats and sediment invertebrates are complex and reciprocal. There is evidence from the Ythan that shells of Hydrobia could facilitate the recruitment of Enteromorpha, and Nereis draws algal filaments into its burrow, presumably in order to feed in safety. Neither Hydrobia nor Corophium had any effect on the Enteromorpha standing crop, but there was evidence for less above-ground algal biomass when Nereis was present. Although the mechanisms underlying the negative effects of Nereis are not well understood, it is possible that such interactions might explain in part the low abundance of macro-algae in the upper reaches of the estuary, where Nereis is most abundant. However, the most dramatic interaction documented on the Ythan is the negative impact of macro-algal 
mats on Corophium, which seems to be independent of the algal species comprising the mats. Given the high occurrence of Corophium in the diets of the Ythan's consumers, it is vital that efforts are made to reduce the impact of macro-algal blooms in this estuary so that the conservation status that the Ythan presently enjoys may continue.

Acknowledgements Thanks go to Scottish Natural Heritage for permission to work on the Ythan estuary; to the Carnegie Trust for funds to visit Sylt in order to discuss this work with participants at the ECSA Workshop, August 1998; to Sue Way for help in collecting and processing much of the data contained herein and for the many postgraduate students on whose work I have been fortunate to draw.

\section{References}

Armonies WA, Hartke D (1995) Floating of mud snails Hydrobia ulvae in tidal waters of the Wadden Sea, and its implications in distribution patterns. Helgol Meeresunters 49:529-538

Balls PW, Macdonald A, Pugh K, Edwards AC (1995) Long-term nutrient enrichment of an estuarine system: Ythan, Scotland (1958-1993). Environ Pollut 90:311-321

Buxton NE (1975) The feeding behaviour and food supply of the common shelduck (Tadorna tadorna) on the Ythan Estuary, Aberdeenshire. PhD thesis, University of Aberdeen

Fletcher RL (1996) The occurrence of "green tides" - a review. In: Schramm W, Nienhuis PH (eds) Marine benthic vegetation: recent changes and the effects of eutrophication. Springer, Berlin Heidelberg New York, pp 7-44

Goss-Custard JD (1966) The feeding ecology of the redshank (Tringa totanus) in winter on the Ythan estuary, Aberdeenshire. $\mathrm{PhD}$ thesis, University of Aberdeen

Green AJ (1977) The production and utilisation of Enteromorpha spp in the Ythan estuary, Aberdeenshire. PhD thesis, University of Aberdeen

Hall SJ, Raffaelli D (1991) Food web patterns: lessons from a species-rich web. J Anim Ecol 60:823-834

Hull SC(1987) Macroalgal mats and species abundances: a field experiment. Estuarine Coastal Shelf Sci 25:519-532

Hull SC (1988) The growth of macroalgal mats on the Ythan estuary, with respect to their effects on invertebrate abundance. $\mathrm{PhD}$ thesis, University of Aberdeen

Joffe MT (1978) Factors affecting the numbers and distribution of waders on the Ythan. PhD thesis, University of Aberdeen
Lawrie S, Raffaelli D (1998) In situ swimming behaviour of the amphipod Corophium volutator. J Exp Mar Biol Ecol 224: $237-254$

Limia J (1989) Bioturbation of intertidal sediments: an experimental approach involving the amphipod Corophium volutator. $\mathrm{PhD}$ thesis, University of Aberdeen

Okora KO (1989) Pollution effects of agricultural run-off on macroalgal growth and population structure/recruitment in the amphipod Corophium volutator on the Ythan Estuary. MSc thesis, University of Aberdeen

Raffaelli D (1998) The community ecology of the Ythan estuary. In: Gorman ML (ed) The Ythan, vol 40. University of Aberdeen, Aberdeen, pp 10-13

Raffaelli D, Hull SC, Milne H (1989) Long-term changes in nutrients, weed mats and shorebirds in an estuarine system. Cah Biol Mar 30:259-270

Raffaelli D, Limia J, Hull SC, Pont S (1991) Interactions between invertebrates and macroalgal mats on estuarine mud flats. J Mar Biol Assoc UK 71:899-908

Raffaelli DG (1999) Nutrient enrichment and trophic organisation in an estuarine food web. Acta Oecol 20:449-461

Raffaelli DG, Raven JA, Poole LJ (1998) Ecological impact of green macroalgal blooms. Annu Rev Oceanogr Mar Biol 36: 97-125

Raffaelli DG, Balls P, Way S, Patterson IJ, Hohman S, Corp N (1999) Major long-term changes in the ecology of the Ythan estuary, Aberdeenshire, Scotland: how important are physical factors? Aquat Conserv 9:219-236

Reise K (1983) Sewage, green algal mats anchored by lugworms and the effects on small Turbellaria and small polychaeta. Helgol Meeresunters 36:151-162

Reise K, Siebert I (1994) Mass occurrence of green algae in the German Wadden Sea. Ger J Hydrogr [Suppl] 1:171-180

Schories D, Reise K (1993) Germination and anchorage of Enteromorpha spp in sediments of the Wadden Sea. Helgol Meeresunters 47:275-285

Shearer G (1997) Interactions between macroalgae and the mudsnail Hydrobia ulvae. Is grazing a causal factor in the development of macroalgal mats on the Ythan estuary, Aberdeenshire. MSc thesis, University of Aberdeen

Ventura L (1997) The effects of the feeding and burrowing activities of Corophium volutator and Nereis diversicolor on the establishment of green algae Enteromorpha spp in an estuarine mudflat. MSc thesis, University of Aberdeen

Walker SJ (1990) The effects of eutrophication in the Ythan estuary on the abundance and distribution of the amphipod Corophium volutator. MSc thesis, University of Aberdeen

Wilhelmsen U, Reise K (1994) Grazing on green algae by the periwinkle Littorina littorea in the Wadden Sea. Helgol Meeresunters 48:233-242 